Psychiatric Bulletin (2004), 28, 15-18

\title{
IN CONVERSATION WITH DORIS HOLLANDER
}

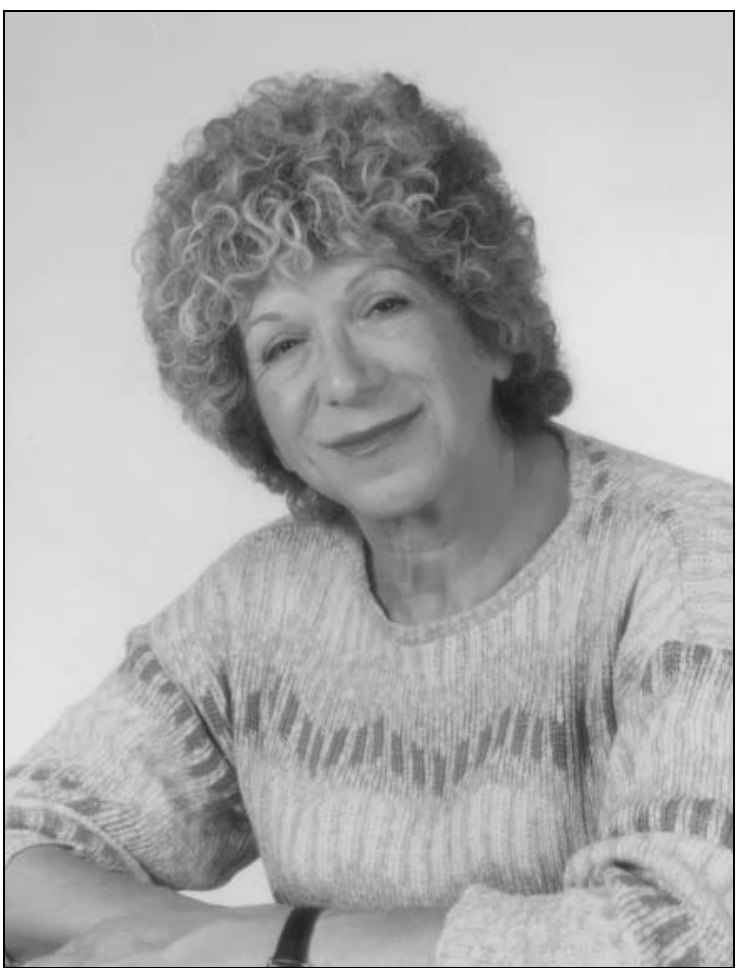

\section{From A to B: Aachen to Bulawayo}

I was born in Aachen, Germany, of Jewish parents in 1936. My father, a factory owner, was helping people passing through from Eastern Europe who were emigrating. He spent some days in gaol himself before being released. In 1939, our family were discussing nightly whether or not to stay in Nazi Germany. Those of my relatives who remained undecided later perished. My parents managed to obtain visas for Southern Rhodesia, where my mother's sister was already living. When we left Germany we passed through Anne Frank's home in Holland because my father was a cousin of Anne Frank's mother (her maiden name was Hollander). From there we went by ship to Cape Town, arriving 8 days before the outbreak of war. We went to Bulawayo, where my father worked in a factory until the end of the war. He then started a scrap metal business, which expanded to become the Central African Metal Trading Company. He did very well. This was important to me as it meant my
Doris Hollander MB ChB FRCPsych MD DPM attended school in Bulawayo, S. Rhodesia, and graduated from University of CapeTown, 1962. After her pre-registration year at Mpilo Hospital, Bulawayo, she pursued training at the Maudsley. In 1969, she became research registrar in the Neuropathology Department, Runwell, where she completed field work for her MD.

She was a London Hospital senior registrar before becoming a locum consultant at Goodmayes and then a consultant psychiatrist for Chelsea and Banstead and St Stephen's. In 1975, she moved to Friern, theWhittington and the Royal Northern Hospitals. In 1981, she became Deputy Secretary for Mental Health at the Ministry of Health, Zimbabwe, until 1986. She then worked as an Islington consultant up to her retirement in 1996. She was a Richmond Fellowship Council member, 1987-96.

She taught diverse personnel: as honorary senior lecturer at the Institute of Psychiatry, she lectured on developing mental health services. In 1987, she proposed a College resolution (seconded by Naomi Richman and Raymond Levy) condemning apartheid and supporting the Commonwealth Nassau Accord. She co-founded CONCERN for the Mentally III, which spearheaded liaison with other organisations to produce a Charter for the Homeless Mentally III.

In 1993, she was in Zimbabwe to facilitate review of the Mental Health Act of Rhodesia, which led to the Zimbabwe Mental Health Act. In 1996, she proposed the College resolution (seconded by Steven Hirsch) urging review of the care in the community policy. After the 1998 bomb blast, she spent three months counselling in Nairobi, Kenya.

parents were able to support me during the years of my training.

Growing up in Rhodesia I had a privileged life. The first time I went to a mental hospital I was about 11. My mother was visiting a Jewish lady who had been admitted, I subsequently learnt, because she had been having an affair with a Black man. She was flown back to England. I do not know if she was mentally ill. When I was 15, I decided to do psychiatry. It sounded interesting, romantic and certainly sophisticated. I was shocked when I realised that I would have to study medicine first. We heard that the best medical school in the world was in Edinburgh, so off I went, kitted out with a lovely suit with a waistcoat and matching beret, and of course high heels. The people in Edinburgh were pleased to see me but said that there was no place for me. In retrospect, to think that I expected them to take me on, just like that, is staggering. 


\section{A student in London and CapeTown}

I applied to medical schools in the UK. At the Middlesex Hospital they said that they took 40 to 60 people a year but that only included 10 women. They were sorry but they could not offer me a place. I then applied to the polytechnics and opted for Chelsea because it sounded arty. I had a wonderful time there, chatting in the refectory and putting the world to rights. I did not pay sufficient attention to my studies and realised that I needed to repeat the whole year. When my parents heard this they said, 'Enough is enough, you come home'.

Back in Rhodesia, I still wanted to do psychiatry and started at Cape Town Medical School. I used to study with a friend. I was very sad when I passed my finals and she failed. Although she was a forceful person with a good sense of humour, she would fold in front of an examiner. You must remember this was apartheid South Africa: she was Asian and the examiners White. In anatomy, all the cadavers were Black and Black students could not attend post mortems on White people's bodies. I never went to any social functions at the University because they were racially segregated. On the other hand, anti-apartheid demonstrations and political meetings were happening all the time.

In Rhodesia, there were three sorts of hospitals: the very basic hospitals for Black patients; the first world type hospitals for Whites; and intermediary ones for people of mixed race and Asians. After qualifying, I worked at a hospital for Black patients.

\section{Psychiatric Training}

I came back to England to train in psychiatry. I first got a medical job as a senior house officer at the Kent \& Sussex Hospital in Tunbridge Wells. It was all beautifully dignified and organised, the wards were spotless and we had a great time. Later I did a neurology job at the Wakefield and when I explained that I wanted to do psychiatry, my consultant introduced me to Max Hamilton. He said 'yes, I can offer you a job and I think the best way for you to set out on your career in psychiatry is to work in a ward full of people suffering with schizophrenia'. My father's general practitioner (GP) in Rhodesia knew Denis Leigh, who was a consultant at the Maudsley, and he gave me a letter to send him asking if he could help with my training. Denis Leigh passed my letter on to Gerald Russell, the Sub-Dean, who said that he would be happy to see me. I came down to London for the interview in the most wonderful purple suit lent to me by my sisterin-law. I was offered a job as a clinical assistant provided my parents could pay for me.

I started at the Maudsley in 1965 with three and then five patients. When you only have three patients, you see them every day and try to know them inside out. After a few months, applications were being invited for registrar posts and so I started paid employment. I first worked for Linford Rees. He taught me the benefits of keeping calm and saying less rather than more. I was now living at the Bethlem and worked for Felix Post in psychogeriatrics. When I came to the Maudsley, Sir
Aubrey Lewis was in charge. We used to take admission and discharge summaries to the admission and discharge rounds and he would tear them to bits. A colleague said, 'The only way I can survive is by thinking of him as a little tailor from Lithuania'. Sir Aubrey had this incredible mind, but also, I believe, a phobia of travelling in cars and he always travelled by bus. This man who had everybody quivering would stand at the bus stop like the rest of us.

Our training concentrated on diagnosis and treatment and looked at drugs, and the social side was left to social workers and psychologists. On Saturday mornings, we all went to the journal club chaired by Sir Aubrey. I remember David Goldberg, Steven Hirsch and Christopher Dare, just to mention a few. The atmosphere at the Maudsley was quite competitive, but it was an amazing place to study, with all the different opinions given at case conferences.

Then in 1967, just before the 6 Day War, I became very concerned about the threat in the Middle East to the survival of Israel. As a result, I abruptly resigned from the Maudsley to go to Israel as a volunteer at a time of crisis. I was sent to work as a doctor on a kibbutz near the Golan Heights. As the war only lasted a week, I was fortunate when Gerald Russell enabled me to return to my old job and resume my training. I worked in the day hospital for Douglas Bennett. I felt he had the right attitude to his patients. For example, he held an evening clinic for people who were at work. The question was what would be my next move. In the neuropathology department we decided that I would do an MD. I went to the department of neuropathology at Runwell Hospital in Essex. My project was to study people who had dementia and when any of them died and had a post mortem, I looked at the brain and would do a clinicalpathological correlation. With the basic research done, but the thesis not written, I chose to go back into clinical work. I went to St Clement's Hospital in the East End as a senior registrar. Although I had been to the Maudsley and passed my exam, I felt overwhelmed, but immensely fortunate to be working with John Denham. By listening to him talking to patients, things began to fall into place.

I had come close to completing my time as a senior registrar and during my holidays I was continuing painstakingly to write my thesis. I felt I needed more time and my mother agreed to pay for me to take time off to finish it. But I was offered a post as a locum consultant psychiatrist at Goodmayes Hospital.

\section{Working as a Psychiatrist}

This was my first experience with long-stay patients. One thing I did not like was that the men were segregated from the women. I was responsible for getting the hospital's first mixed long-stay ward opened. We were becoming aware that there were people who had been in the hospital for many years who did not need such care. I remember discharging a patient who had been there for 50 years and he went to a nice home in Herne Bay. Until then my patient had always looked a bit dishevelled. He changed after discharge. He became more debonair with a trilby hat with a feather and a three piece suit. He 
would walk to the shop every day, get his tobacco and go for a stroll on the sea front. He had taken to his new life with relish.

I left Goodmayes for a permanent job at Banstead Hospital, with out-patients at St Stephen's Hospital (now the Chelsea and Westminster Hospital). I was able to get support to move some of the patients off the ward and into the hospital's first pre-group home. Being a little political, I also organised ward meetings chaired by patients. These went very well. In Chelsea, I found many transient young people who had depression, drug problems, or had taken an overdose; large council estates where there was chronic illness; and a more affluent social group who engaged in heavy drinking.

I was living in Hampstead at the time and friends said, 'Why not come to Friern?' My predecessor Howard Sergeant had begun a mammoth scheme of discharging people from hospital. I found myself in a situation that was already vibrant in terms of getting community psychiatry off the ground. I was very lucky to be helped by the occupational therapists in starting a socialisation scheme. People came through for 2 weeks at a time to learn what we now term activities of daily living. I was impressed with the atmosphere at the industrial workshop: people seemed to be more focused when they were engaged in work, even though it was repetitive, and the atmosphere was relaxed.

There was something about the large wards that was very institutionalised. We would try to move chairs into little groups around small tables but it did not work. Later I realised that everyone needed to be able to carve out their own private area because this was essentially open-plan living, 24 hours a day. By always sitting in the same chair, the patients were respecting each other's privacy. It was all they had. We moved some people on away from the hospital. Afterwards people frowned that patients were 'dumped' in Margate, but it was not like that. We did preparatory visits. Patients had their own room or shared with one or two others. They had their own front door keys. These were great improvements. Patients felt free.

\section{Health for All}

I went back to Rhodesia, now Zimbabwe, in 1981. In 1980, I had been invited to do a tour of inspection of the mental hospitals after independence by Dr Herbert Ushewokunze, the first Zimbabwean Minister of Health, and I was asked to become deputy secretary for mental health services in Harare. I was married by then and my husband came as well. That was a really exciting time in both mental health and development terms. In 1978, the World Health Organization (WHO) had launched 'Health for All by the Year 2000', a scheme to bring basic health care to everybody worldwide. Education and proper care for children and mothers including family planning, immunisation, nutrition, clean water and sanitation, essential drugs, communicable disease control and prevention, and basic curative care. Zimbabwe getting its independence after a bitter liberation struggle was very concerned to improve its healthcare. Until then, 30 times more money went into health for White people compared with that for Black people living in the rural areas. Now there were deputy secretaries for Medical Services, Rural Health Care, Health Planning, as well as Mental Health. All four of us toured the country. You were expected to turn your hand to whatever came up, whether it was a medical problem, a child health issue, a question to do with $\mathrm{X}$-rays or even the drains. I knew from the start that I had a challenge because I was in mental health and because of the stigma associated with it.

I remember once trying to use my charm to wangle more resources from the permanent secretary, and he said, 'Doris, I don't know why you want all this for mental health. We've got our own resources for mental health' and of course that was true. In Zimbabwe the traditional healers are everywhere and people consult them to this day.

Conditions before independence for Black patients in hospital were dreadful. Huge cement-floored halls with no seating and just a pathetic fire in winter. Patients were forced to wear uniforms of blue cloth and had their heads shaved. Electroconvulsive therapy was given without anaesthetic. These were things we wanted to and did change. The government put through a programme of changes. They paid for beds, linen, blankets, pillows, clothes, underwear and shoes for the patients. There were no longer separate wards for Black and White patients. We put in windows on the outer walls. From being dark damp holes, the wards were suddenly light and airy rooms. I remember one occasion when we visited a locked ward and opened the door. For the first time in years patients were able to touch the soil, grass and trees. Some of the women began to dance.

We developed a country-wide community psychiatric nurse service. The nurses were so excited about going out into the community with antidepressants and antipsychotic drugs. The WHO holds an annual meeting in Geneva attended by all the health ministers and there was a special African Mental Health Action Group. Norman Sartorious, of the WHO, took an interest in Zimbabwe and suggested we had an international conference. A booklet came out of it and we really felt that we were moving towards a national integrated and intersectoral system for mental health.

Training was a central aim of government. With Cynthia Chasokela and other colleagues, we fought to get a psychiatric component into the basic training for nurses. When the nurses qualified we were very firm: a third would stay at the central teaching hospitals, a third would go to the other hospitals and a third to the rural areas. That form of decentralisation of services was fundamental to what we were doing. At independence a new cadre was created, the village health worker. Everybody was fighting for a bit of the village health worker training: we wanted to put in mental health, others wanted to put in sanitation, nutrition and clean water, maternal and child health, etc. Mental health was only given one lecture but we made up for it as our community psychiatric nurses (CPNs) were coming into contact with these workers on the ground in the rural areas all the time, so very nice links were established this way. In 
(8)

special article the end, the village health worker came under another Ministry and the role in relation to health was diluted. This was a real loss once the AIDS epidemic started.

\section{Mental Health Promotion}

After five years, I left Zimbabwe for personal reasons, but I have retained my interest in the country and have visited regularly. On my return to London, I went back to Friern Hospital and the Whittington Hospital as a locum and eventually got the community job. I started holding clinics in health centres as a way of providing a local service. The CPNs worked with me in providing community care. I really enjoyed the contact with GPs and social services and being close to where people were living. I also took over half an admission ward. That was a good thing in terms of keeping me in touch with acute work and making me aware of the pressure on beds. I could see that with the planned closure programme there was going to be trouble with beds, because we were already under pressure on the admission ward.

I used to have lunch in the canteen, where I would bump into Malcolm Weller and discuss the way they were going ahead with the closure programme, sending patients out without proper facilities even though the government was saying no patient was going to go without adequate provision. Malcolm and I decided to start an organisation (CONCERN) for doctors, nurses, social workers, occupational therapists and the general public, saying that we were in favour of community care, but that we did not wish to see hospitals shut before there were adequate services up and running in the community. We were quite a militant group and we held public meetings. Mrs Thatcher was the local MP and I remember talking to her. I think she had mixed feelings about the closure of all those hospitals. There were other powerful organisations saying, 'It has got to happen now'. Once someone at Region had said 'If you close the hospitals and sell the land, that will provide for reprovision', the idea really took off. There was no shortage of people who could point to all the terrible things in the old hospitals and disregard their positive side.

What I find very hopeful now is the publicity afforded to mental health issues. To see women's magazines full of articles starting with premenstrual syndrome and moving onto anxiety states, depression, schizophrenia and so on. To see the College coming along with a whole campaign against stigma. I was very happy as a psychiatrist, with such interesting and varied work, and it was so heart warming to work with people, to see them through their illnesses, to see them come out of it. And also to have the privilege of working with nurses and people who did not get better, to allow us to say to them, 'Your life is worthwhile, you may not be well, but your life is as worthwhile as anybody else's'. 